\author{
Adnan Fateh, \\ University of Malaya, Malaysia \\ email: cva180020@siswa.um.edu.my \\ Norizah Mustamil, \\ Ph.D., University of Malaya, Malaysia \\ email: norizahmm@um.edu.my \\ Muhammad Zia Aslam, \\ University of Malaya, Malaysia \\ email: aslam101m@gmail.com \\ Correspondence author: norizahmm@um.edu.my

\section{LINKING AUTHENTIC LEADERSHIP AND EMPLOYEE CREATIVE BEHAVIOR: THE MEDIATING ROLE OF AUTONOMOUS MOTIVATION AND JOB COMPLEXITY}

Abstract. The main purpose of this study is to determine the relationship between authentic leadership and employee creative behaviour and to reveal two different mediating mechanisms (i.e., job complexity and autonomous motivation) through which authentic leadership influences employee creative behaviour. This study is based on selfdetermination theory. A total of $(N=354)$ respondents were asked to rate themselves on creative behaviour and their leader on authentic leadership style. The research used the internet-based survey tools in a cross-sectional. The study population was employees (mainly Software Developers) of software houses (software companies) working in Pakistan. Methodological tools of the research were partial least square structural equation modelling (PLS-SEM) for measuring the relationship between the variables. The results of the study show that authentic leadership positively influences employee creative behaviour directly as well as through two competing mechanisms of job complexity and autonomous motivation. Job complexity and autonomous motivation were tested as mediators between authentic leadership and employee creative behaviour independently and comparatively. Both the mediators successfully mediated the relationship between authentic leadership and employee creative behaviour with variable strength. The mediation path of job complexity was stronger in comparison with the mediation path of autonomous motivation. Further examination revealed that job complexity and autonomous motivation both mediate the relationship between authentic leadership and employee creative behaviour in a sequential manner. The results of the study are useful for both practitioners and researchers equally. For practitioners, the authors laid out the process through which managers can foster the creative behaviour of their employees using an authentic leadership style (i.e., by giving increased opportunities to indulge in complex work). Furthermore, for researchers, this study revealed the mechanisms through which authentic leadership influences and predicts creative behaviour. The findings of the study would benefit the authentic leadership theory for further development as a predictor of positive employee outcomes as this study confirmed a relatively complex mechanism through which it influences the creative behaviour of his followers.

Keywords: authentic leadership, autonomous motivation, creativity, employee creative behaviour, job complexity, self-determination theory, software houses of Pakistan, software developers.

Introduction. Nowadays, organizations are facing a complex-competitive environment where the margin for gaining competitive advantage is getting thinner. Creativity offers a unique benefit for achieving and maintaining a competitive advantage in a highly competitive environment (Anderson, De Dreu, \& Nijstad, 2004). It is the employee's creative behaviour, which reflects in the broader organizational creativity. Employees of the organization, from senior management to front line staff, contribute to the organization's creativity at some level (Zhou \& Ren, 2012). Organizations try to maximize the creative potential of their employees through different strategies, from recruiting creative employees (i.e., employees with creative potential based on personality types) and further motivating them by providing

Cite as: Fateh, A., Mustamil, N., \& Aslam, M. Z. (2020). Linking Authentic Leadership and Employee Creative Behavior: The Mediating Role of Autonomous Motivation and Job Complexity. Marketing and Management of Innovations, 3, 59-74. http://doi.org/10.21272/mmi.2020.3-05 
A., Fateh, N., Mustamil, M. Z., Aslam. Linking Authentic Leadership and Employee Creative Behavior: The Role of Autonomous Motivation and Job Complexity.

complex work that requires methods beyond traditional for successful performance. Moreover, the most critical factor for any organization to success is its leadership (Tracy, 2010), which enables conditions and environment that facilitate or hamper creativity in the organization.

This research also supports the assertion that leadership is a significant influencer of employee creative behaviour (Zaitouni \& Ouakouak, 2018). Meta-analysis and review papers have highlighted the leadership as the essential determinant of employee creativity (Anderson et al., 2014; Hughes et al., 2018). However, empirical research on leadership and the creative outcome has still not as per expectations given the importance of leadership in shaping the follower's behaviour, and what type of leadership is the most suitable for predicting employee creative behaviour remains unanswered. The scholars have made calls for more research on a broader canvas of positive leadership styles, which can facilitate creative behaviour among their followers (Anderson \& Sun, 2017). In turn, the studying authentic leadership (AL) for this purpose is merited because it has the capability for such a need. AL style has the potential to stand out among other leadership styles concerning creative behaviour of his followers because it has the highest amount of self-awareness in comparison with any other leadership type (Walumbwa et al., 2008). And authentic leader's self-awareness is necessarily his creative self, which "reverberates» with his followers (Gardner et al., 2005). The innate component of self-identity is anchored in positive psychology with a focus on positive behaviours (Luthans \& Avolio, 2003), which makes it the ideal candidate for studying with creativity. AL has gained little research attention as compared to other leadership styles, such as transformation leadership and empowering leadership regarding the follower's creative behaviour (Hughes et al., 2018). AL is a relatively novel construct, still in its infancy, and research on its relationship with positive employee attitude and behaviour, such as creativity, is nascent (Chaudhary \& Panda, 2018). Even though there is a good amount of theoretical support in the literature for the claim that AL can predict creative behaviour. However, still, empirical studies connecting it with creative behaviour are in dearth, let alone the studies investigating the mechanisms through which is influences creative behaviour. For example, a recent review paper on leadership and creative behaviour concludes that studies of transformational leadership to creativity and AL to creativity has a ratio of 1:5 (Hughes et al., 2018). Another meta-analysis found the number of studies connecting AL with creative behaviour was one third as compared to transformational leadership. However, it explained the largest amount of variance in creative behaviour in comparison with other leadership styles (Lee et al., 2020). Therefore, the study is justified exploring predictive $A L$ role with creative behaviour in addition to answering the calls for investigating the relationship between $\mathrm{AL}$ and creativity. This study tried to bridge the research gap by examining the underlying mechanisms through which authentic leader effect creative behaviour of his followers as very little is known about the process through which authentic leader influence his follower's creative behaviour (Rego et al., 2014). A few of the mechanisms studied between AL and creative behaviour so far are affective commitment (Ribeiro et al., 2020), hope and positive affect (Rego et al., 2014), employee psychological capital (Rego, Sousa, Marques, \& Cunha, 2012), work-related flow (Zubair \& Kamal, 2017), work engagement and psychological empowerment (Mubarak \& Noor, 2018), happiness (Semedo, Coelho, \& Ribeiro, 2017), and at the team level, leader-member exchange (LMX), and team psychological safety (Xu et al., 2017). However, there is a need to explore the additional mediating mechanism of $A L$ and creative behaviour (Ribeiro et al., 2020).

The current research investigates the AL role in predicting employee creative behaviour and the process through which it affects creativity. Therefore, it adds value to the nascent AL literature and pave the way for its further development as a positive leadership style capable of predicting critical employees behaviour such as creative performance. With this idea in mind, there is a hypothesis that AL predicts creative behaviour directly and through two mechanisms; first through autonomous motivation and other job complexity. Moreover, none of the studies has examined the job complexity and autonomous 
A., Fateh, N., Mustamil, M. Z., Aslam. Linking Authentic Leadership and Employee Creative Behavior: The Role of Autonomous Motivation and Job Complexity.

motivation mechanisms previously as the mediating mechanism between $\mathrm{AL}$ and employee creative behaviour.

Literature Review. Walumbwa et al. (2008) define AL as a pattern of leader behaviour that draws upon and promotes both positive psychological capacities and a positive ethical climate, to foster greater self-awareness, an internalized moral perspective, balanced processing of information, and relational transparency on the part of leaders working with followers, fostering positive self-development". An authentic leader influences his follower using positive modelling, and his actions based on his values and convictions. Confidence, hope, and resilience are the psychological resources of an authentic leader. AL construct consists of four dimensions. The first one is self-awareness which refers to the understanding of how one makes meaning of the world and how those meanings affect the image of himself. It also signifies the understanding of the individual towards his strengths and weaknesses (Walumbwa et al., 2008). The second dimension is relational transparency, which means presenting the original self to others and not faking or creating false impression via fostering a climate of trust and safety where the authentic leader does not feel threatened (Gardner, Avolio, \& Walumbwa, 2005). The third is balanced processing, where the leader objectively analyses information before making decisions and does not shy away from challenging deeply held positions (Gardner, Cogliser, Davis, \& Dickens, 2011). The fourh dimention is internal moral perspective referring to the high moral standards guided by internal standards and values rather than external motivators or pressures. It is internalized and integrated form of self-regulation where individual achieves self-determination through the process of self-regulation (Ryan \& Deci, 2003). This study based on the self-determination theory SDT (Deci \& Ryan, 1985b). SDT argues that every human being has three basic psychological needs as follows: the need for autonomy, need for competence and need for relatedness. When all three needs are fulfilled, an individual becomes self-determined and acts on his own volition. SDT is suitable for studying AL with employee outcomes because both the theories (i.e., authentic leadership and SDT) share a significant overlap (Miniotaite \& Buciuniene, 2013).

There is a debate in the literature about the similarity and overlap of $A L$ with various forms of positive leadership styles such as transformational leadership, ethical leadership, servant leadership. The overlap is understandable because $\mathrm{AL}$ is theorized as the "root construct» underlying all forms of positive leadership (Avolio \& Gardner, 2005). However, research has demonstrated its uniqueness (Neider \& Schriesheim, 2011). Besides, some studies have shown its preeminence over transformational leadership on selected outcomes (Banks et al., 2016). In a recent meta-analysis, AL dominated on other forms of leadership on its correlation with employee creative behaviour (Lee et al., 2020). The role of leadership for inducing employee creative behaviour is of utmost importance given the authority of leadership in shaping various aspects of organisational and work environment. This study seeks to determine the relationship between $\mathrm{AL}$ and employee creative behaviour. $\mathrm{AL}$ possesses necessary positive psychological capital, and his actions are grounded in internal ethical and moral standards. The very building block of $A L$ is what makes it most relevant for employee creative behaviour. For example, through a relational transparency component, an authentic leader ensures the transparent flow of information between him and his follower. Such an exchange of information flow forms the environment of trust and safety (Agote et al., 2016), where the follower is not afraid of expressing his new ideas and receives transparent feedback for his efforts. Constructive feedback has shown to enhance creative behaviour (Christensen-Salem et al., 2018). AL is the form of leadership with high self-awareness (Walumbwa et al., 2008) and transfers it to his follower through modelling and relational. «Authentic leaders are originals, not copies» (Avolio \& Gardner, 2005). Followers reciprocate the process of self-awareness as they identify their strengths, weaknesses, and real self. As they become more self-aware, they become more transparent with the leader and present original thoughts and ideas without any fear.

Furthermore, authentic leader actions are synonym with his values, and he cannot present himself as something which he is not. Creative behaviour is coming up with original The inspiration from the leader 
A., Fateh, N., Mustamil, M. Z., Aslam. Linking Authentic Leadership and Employee Creative Behavior: The Role of Autonomous Motivation and Job Complexity.

resonates with the followers (Walumbwa et al., 2008), and they may exhibit more originality and authenticity. Moreover, the authentic leader motivated his followers by giving them a sense of purpose for delivering new and innovative products and services (George, 2003). Thus, this study provides the following hypotheses.

$\mathrm{H} 1$ : AL positively predicts employee creative behaviour.

Componential theory of creativity (Amabile, 1988) terms motivation as an essential precursor for creative endeavours, intrinsic motivation to be specific. It was argued that the foci for creativity lie within an individual (i.e., intrinsic motivation). Creative behaviour necessitates an internal focus of causality; otherwise, it withers (Deci \& Ryan, 1985a). Perception of control from external sources only serves a detrimental purpose in employee creative behaviour. The proximity of intrinsic motivation with creativity is well documented in the literature (de Jesus et al., 2013; Sajjad et al., 2020). However, there is equal evidence of extrinsic motivation's positive effect on creative behaviour when appropriately used (Eisenberger et al., 1998; Eisenberger \& Cameron, 1996, 1998). Recently Amabile and Pratt (2016) acknowledged the role of external motivators when used in addition to intrinsic motivation. The question arises on how to use intrinsic and extrinsic motivation together. Self-determination theory (SDT) (Ryan \& Deci, 2000) can provide a remedy in this situation. SDT proposes a unique type of motivation that encompasses elements of extrinsic motivation and intrinsic motivation in one broader assemblage called «autonomous motivation». In the study, it is proposed that autonomous motivation can predict creative behaviour because it contains the best of both worlds (e.g., intrinsic motivation and extrinsic motivation). Herewith, AL leads to autonomous or self-determination type of motivation because an authentic leader not only model's self-determination through the process of internal self-regulation but also supports his follower's self-determination (Avolio \& Gardner, 2005). When the follower imitates the self-determination of his leader, he acts volitionally without any external inducement and thus indulges in creative behavior. Thus hypothesized.

H2: AL positively affects autonomous motivation.

H3: Autonomous motivation mediates the relationship between AL and creative behaviour.

One of the most crucial considerations for the study of employee creative behaviour is work design. For an individual to exhibit creative behaviour, the first and foremost thought is, if the job allows creativity. Work design has been recognized as a key influencer of important work outcomes, including creativity, because of the motivational consequences of job characteristics (Parker et al., 2017). If the job is routine and follows strict performance guidelines, there is minimal potential for individuals to employ novel methods for successful performance. Componential theory of creativity recognizes job characteristics influence under the job-relevant skills requirement because a routine and simple job dampen the intrinsic motivation (a prerequisite of creative behaviour) (Amabile, 1996). Job characteristics model JCM (Hackman, 1980) is one of the most comprehensive models of job characteristics. It has been widely used in literature for testing its effect on creative behaviour (Tierney \& Farmer, 2002). Furthermore, job complexity directly appeals to the need for the competence of an individual. The need for autonomy is fulfilled when an individual is allowed to perform with his method of choice. Because complex jobs require a creative problem-solving approach where an individual deploys multiple approaches of successful performance (Mumford et al., 1994) hence fulfilling the need for autonomy. Complex jobs are highly interdependent and require feedback and participation from multiple participants (Van Der Vegt et al., 2000), therefore fulfilling the need for relatedness. When three basic psychological needs are fulfilled, an individual becomes self-determined or autonomously motivated (Deci et al., 2017). Whereas, the authentic leader rationally debates the long-held positions and makes data-oriented decisions. He interacts, questions, and debates on finding creative solutions to the problems (Nichols \& Erakovich, 2013). By basing his decision on objective data, he does not shy away from facing complex issues at work. An authentic leader does not control his followers; he let them make their own decisions and empower them 
A., Fateh, N., Mustamil, M. Z., Aslam. Linking Authentic Leadership and Employee Creative Behavior: The Role of Autonomous Motivation and Job Complexity.

to find solutions to the problems on their own. Meanwhile, he supports, encourages, and validates their potential. AL is the type of leadership required in the complex work environment (Toor \& Ofori, 2008). Moreover, AL provides constructive feedback developmentally (llie et al., 2005), an important antecedent of employee creative behaviour. On the assumption, AL provides opportunities for his followers to perform work that empowers them, provides autonomy, feedback, and support, in short, all the necessary attributes of a complex job. Futhermore, job complexity mediates the relationship between creative behaviour. Previously job complexity has been used as a mediator between various types of leadership and various employee outcome variables (Parker et al., 2017). Thus Hypothesis.H4: Authentic leadership positively affects employee creative behaviour.

H5: Job complexity positively affects employee creative behaviour.

H6: Job complexity positively affects autonomous motivation.

H7: Job Complexity mediates the relationship between authentic leadership and employee creative behaviour.

The discussion above leads to the inference that $\mathrm{AL}$ influences not only creative behaviour directly but also through different mediating mechanisms. It was postulated that authentic leader influences work design in such a way that it provides employees with opportunities for working on complex work. Moreover, AL stimulates the basic psychological need satisfaction of his followers, hence, making them autonomously motivated and indulge in creative behaviour. There was further contested that AL leads to autonomously motivated employees through his influence on job complexity and then to creative behaviour in a sequential mediation process. The study supports the proposed sequential mediation mechanism by relying on historical evidence of job complexity meditating role with various leadership and dependent variables (Parker et al., 2017). Likewise, AL positively influences intrinsic motivation (llies et al., 2005), intrinsic motivation not only triggers creativity (Amabile, 1988) but also shown to have mediated the relationship between AL and creativity (Ahmad et al., 2015). Instead of intrinsic motivation, the autonomous motivation was used as a mediator because it contains elements of intrinsic motivation and internalized extrinsic motivation and is better in quality in prediction behaviour on heuristic behaviours such as creative behaviour (Gagne \& Deci, 2005). Based on these theoretical assertions, the sequential mediation hypothesis has been posited. Similar theoretical logic has been used in previous studies with respect to transformational leadership and outcome variable (e.g., Boies, Fiset, \& Gill, 2015). Thus there is hypothesized.

H8: The relationship between AL and employee creative behaviour is mediated by job complexity and Autonomous motivation.

Methodology and research methods. The data was collected from employees of software companies in four major cities (Lahore, Karachi, Faisalabad, Islamabad) Pakistan. The target population for this study was software developers. Human resource departments of these organizations were approached, and their permission was obtained for distributing the survey form to their employees. The survey instrument was circulated on the organizational intranet using an electronic survey tool google forms. Internet-based survey tools are ideal for their speed, convenience, economy, and simplicity (Sue \& Ritter, 2012) and consistent with the pencil paper or other traditional techniques (Gosling et al., 2004). A screening question was placed at the beginning of the questionnaire to screen for non-developers and other administrative staff. Respondents were not asked for their identity, and a statement of anonymity was part of the questionnaire to ensure the respondents of their information privacy. The first reminder was sent to the recipients after one week of the date from the day survey was administered. The second reminder was sent two weeks later to maximize the response. A total of $(N=354)$ respondents completed the survey form. All questions were compulsory to answer; therefore, there was no missing data.

The final sample of $(\mathrm{N}=354)$ shows that $62(28.8 \%)$ respondents were in $20-25$ years age bracket, $162(47.1 \%)$ belong to 25 to 30 years bracket, $52(15.1 \%)$ were in $30-35$ years age group and $31(9 \%)$ 
A., Fateh, N., Mustamil, M. Z., Aslam. Linking Authentic Leadership and Employee Creative Behavior: The Role of Autonomous Motivation and Job Complexity.

were more than 35 years of age. Male respondents accounted for 86.9 percent $(n=299)$ of the respondents, and only 13.1 percent $(n=45)$ were female. The educational level of the respondents varied from Intermediate $(n=6 ; 1.7 \%)$ Bachelor's Degree $(n=211 ; 61.3 \%)$ Master's Degree $(n=119 ; 34.6 \%)$ Ph.D. $(n=5 ; 1.5 \%)$ and others educations $(n=3 ; 0.9 \%)$. Furthermore, $108(31.4 \%)$ of the respondents had less than a year experience, $79(23 \%)$ had 3 to 5 years of experience, $54(15.7 \%)$ had 5 to years of experience, and $71(20.6 \%)$ of the respondents had more than 8 years of experience. The instruments used for the measurement of the variables of the study are listed below.

Creativity was measured scale by Tierney, Farmer, and Graen (1999). The measurement has nine items and has a Cronbach alpha of $a=0.94$. In the current study, the respondents were asked to rate themselves on creative behaviour. The subjective and self-reported operationalization for employee creative behaviour were used because creativity as a phenomenon requires a lot of «subjective judgment» because of its relative nature (James \& Drown, 2012). Self-report creativity is found to have convergence with supervisor-reported creative behaviour (Hughes et al., 2013).

The autonomous motivation was assessed using a six-item multidimensional work motivation scale (MWMS), $a=0.94$ (Gagne et al., 2015). Authentic leadership as a higher-order construct with four dimensions was measured using a fourteen-items scale Authentic Leadership Inventory (ALI), $a=0.87$ (Neider \& Schriesheim, 2011).

Job Complexity is measured using incumbent based job characteristics perception drawn from the Job Characteristics Model (Hackman, 1980). Though there are two methods of measuring for job complexity using JCM; first is the Multiplicative Combinational Index (i.e., Motivational Potential Score-MPS), and second is the simple additive index. Job relative score of all five dimensions of Job Characteristics Model was used to form a single unweighed additive index for complexity perception of the incumbent as it has been previously reported in the literature (Baeret al., 2003; Chae \& Choi, 2018). The single unweighted additive score is better than the multiplicative combination when predicting vital psychological outcomes, performance, and satisfaction (Fried \& Ferris, 1987). Also, multiplicative indexes such as MPS comprise of two cross-product terms which inflate measurement errors (Evans, 1991). A simple additive score has equal weights of different job attributes. Thus, a complex job is perceived as entailing independence for task performance, opportunity to use variable skills, provide feedback, and allows initiating and completing an entire significant piece of work.

For data analysis purpose, partial least square structural equational modelling (PLS-SEM hereafter) technique was used. It is a prediction oriented, a variance-based technique which maximises the explained variance of a latent construct and offers an appropriate solution in the scenario where prediction is the primary goal of the study (Barroso et al., 2010). This approach provides many benefits as compared to other co-variance based structural equation modelling (CB-SEM) techniques. For example, it does not require distributional requirement of normality of data. It can handle different types of latent variables (e.g., formative or reflective). Likewise, sample size requirement is not stringent as PLS-SEM is at ease with relatively small sample size and offers flexibility when dealing with complex models containing a large number of variables (Hair et al., 2011). When the purpose of the study is to determine the predictability of various independent variables on dependent variables and the researcher wants to test a theoretical model, PLS-SEM is suitable to employ (Hair et al., 2014). Nowadays, the main emphasis of management research is prediction oriented because of its implications for managerial decision making, and PLS-SEM provides suitable input for such micro-level predictive decision making. This ability of PLS-SEM contributes toward theory evaluation and theory improvement based on the predicted outcomes (Shmueli et al., 2016). Another advantage of using is that PLS-SEM enables the research to gain a complete picture of the study model because it tested the complete model simultaneously (Gefen \& Straub, 2005). Additionally, PLSSEM technique has become an effective tool for studying complex models in the fields of marketing, strategic management, management information systems, tourism, hospitality, accounting, supply chain 
A., Fateh, N., Mustamil, M. Z., Aslam. Linking Authentic Leadership and Employee Creative Behavior: The Role of Autonomous Motivation and Job Complexity.

management (Sarstedt, et al., 2019), and human resources (Ringle et al., 2020). The SmartPLS 3.3.2 was used for the analysis of the research model.

Results. In the frame of this study, AL was theorized as a higher-order construct with four dimensions and based on a reflective approach. Previous studies have confirmed the multidimensional structure of $A L$ and recommended its usage as a reflective construct. Because the exact contribution of dimensions towards the construct has not known, and its dimensions overlap each other (Lee \& Cadogan, 2013). Job complexity is the average score of all five job characteristics of JCM. Both autonomous motivation and employee creative behaviour are theorized as single order constructs with reflective indicators. Higherorder constructs measurement model specification was performed using repeated indicator approach (Sarstedt, Hair, Cheah, Becker, \& Ringle, 2019). Table 1 shows the correlation and descriptive statistics of the population.

Table 1. Correlation and descriptive statistics

\begin{tabular}{|c|c|c|c|c|c|c|c|}
\hline & Mean & Std & & 1 & 2 & 3 & 4 \\
\hline Creativity & 3.77 & 0.61 & & 1 & & & \\
\hline Autonomous Motivation & 5.28 & 1.05 & ** & 0.546 & 1 & & \\
\hline Authentic Leadership & 3.76 & 0.73 & ** & 0.398 & $0.449^{* *}$ & 1 & \\
\hline Job Complexity & 5.27 & 0.1 .17 & ** & .0487 & $0.609^{* *}$ & $0.506^{*}$ & 1 \\
\hline
\end{tabular}

Note: $(\mathrm{N}=354) \mathrm{SD}$ is Standard Deviation. Matrix represents two-tailed Pearson Bivariate Correlation. Correlation is significant at the ${ }^{* *}<0.01$. Job Complexity is a simple aggregate of job description model.

Sources: developed by the authors.

Measurement model analysis is presented in Table 2 Reliability statistics for employe creative behaviour ( $\alpha=0.859$; $C R=0.890)$, autonomous motivation $(\alpha=0.889 ; C R=0.915), A L(C R=0.790)$ are above the required (i.e., Cronbach's alpha $a \geq 0.70$; Composite reliability $C R \geq 0.70$ ) threshold. Job complexity is theorized as a complexity index. Hence, no need to report measurement statistics except the factor loading, which is one because it is being treated as a single item construct. The average variance extracted (AVE) and indicators loadings were examined to ensure convergent validity. One indicator of creativity $(C R 4=0.611)$ was removed to enhance the construct AVE that was below the acceptable level of 0.50 . Indicators below the value of 0.708 should be removed ideally (Hair et al., 2020) but if AVE is above the required value of 0.50 , then indicators above the values of 0.60 can also be retained (Ramayah et al., 2016). Therefore following these guidelines, all indicators above the values of 0.60 were retained. AVE values for all the constructs of the study (both unidimensional and higher-order multidimensional) are above the desired value of 0.50 (Ringle et al., 2014), establishing convergent validity. Discriminant validity is an essential metric for establishing construct validity for latent variables. Discriminant validity is the minimum standard a social scientific instrument must meet (Campbell \& Fiske, 1959). Discriminant validity is used to ensure «that each construct is empirically unique and captures a phenomenon not represented by other constructs in a statistical model» (Franke \& Sarstedt, 2019). There were used two tests for establishing the discriminant validity of the constructs of the study: Fornell-Larcker (Fornell \& Larcker, 1981) and HTMT (Hetrotrait-Monotrait) (Henseler et al., 2015). Table 3 shows the results of the FornellLarcker test for discriminant validity.

The analysis presents that square roots of AVE of all the constructs of the study listed in the diagonal line correlate higher with the construct itself than other constructs of the study. HTMT is recommended as the updated method of establishing discriminant validity (Hair et al., 2020). 
A., Fateh, N., Mustamil, M. Z., Aslam. Linking Authentic Leadership and Employee Creative Behavior: The Role of Autonomous Motivation and Job Complexity.

Table 2. Measurement model specification

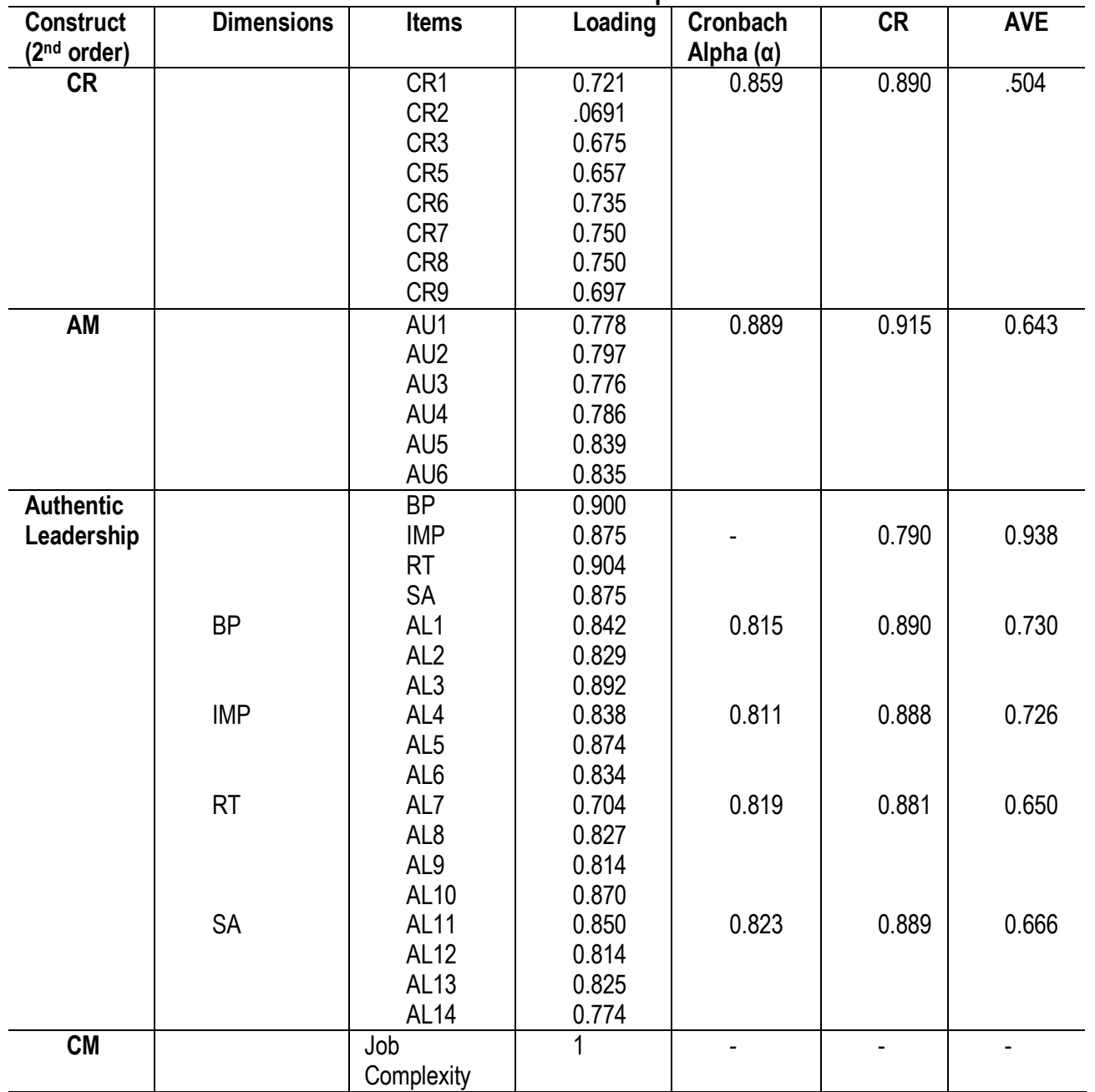

Note: CR is employee creative behavior, AM is autonomous motivation, BP is Balanced Processing, IMP is internal moral perspective, RT is relational transparency, SA is self-awareness.

Sources: developed by the authors.

Table 4 presents the results of HTMT 0.85 criterion. HTMT values for all the variables of the study are above 0.85 establishing discriminant validity. Moreover, bias-corrected intervals do not straddle the value of 1 (one) between the intervals providing additional evidence of discriminant validity.

Single source data is susceptible to common method variance. Since all the variables of the study were collected from an individual respondent, it was devised multiple remedies for dealing with common method variance.

First, respondents were not asked for their identity to discourage the social desirability bias. The different behavioural anchors were used for measuring both the dependent and independent scales to create a psychological barrier (Podsakoff et al., 2003). Additionally, the study provides the marker variable when collecting data to test if the common method variance is present in the study. 
A., Fateh, N., Mustamil, M. Z., Aslam. Linking Authentic Leadership and Employee Creative Behavior: The Role of Autonomous Motivation and Job Complexity.

\begin{tabular}{lcccc}
\hline \multicolumn{4}{c}{ Table 3. Fornell-Larker } \\
\hline & $\begin{array}{c}\text { Authentic } \\
\text { Leadership }\end{array}$ & $\begin{array}{l}\text { Autonomous } \\
\text { Motivation }\end{array}$ & Complexity & Creativity \\
\hline Authentic Leadership & $\mathbf{0 . 8 8 9}$ & & & \\
$\begin{array}{l}\text { Autonomous } \\
\text { Motivation }\end{array}$ & 0.491 & $\mathbf{0 . 8 0 2}$ & & \\
Complexity & 0.52 & 0.625 & 1 & \\
Creativity & 0.432 & 0.545 & 0.476 & 0.71 \\
\hline
\end{tabular}

Note: Square Root of Average Variance Extracted (SQRT-AVE) is shown in bold on the diagonal line, whereas other entries stand for the squared correlations between variables.

Sources: developed by the authors

Table 4. HTMT results

\begin{tabular}{|c|c|c|c|c|}
\hline & $\mathrm{AL}$ & $A M$ & $\mathrm{CM}$ & CR \\
\hline \multicolumn{5}{|l|}{$\mathrm{AL}$} \\
\hline AM & $\begin{array}{c}0.540 \\
(0.430,0.641)\end{array}$ & & & \\
\hline CM & $\begin{array}{c}\mathbf{0 . 5 4 4} \\
(0.429,0.636)\end{array}$ & $\begin{array}{c}0.660 \\
(0.581,0.730)\end{array}$ & & \\
\hline CR & $\begin{array}{c}\mathbf{0 . 4 8 6} \\
(0.358,0.602)\end{array}$ & $\begin{array}{c}0.616 \\
(0.509,0.715)\end{array}$ & $\begin{array}{c}\mathbf{0 . 5 1 2} \\
(0.390,0.614)\end{array}$ & \\
\hline
\end{tabular}

Note: Parentheses represents bootstrapped bias-corrected 95\% confidence interval (LL, UL) at 0.05 significance level. All values in bold represent HTMT ratio of correlations (Less than HTMT0.85). AL is authentic leadership; AM is autonomous motivation; CM is job complexity; CR is creative behaviour.

Sources: developed by the authors.

There is used a «blue attitude» as a marker variable. It is theoretically different from the constructs of the study. The technique used for employing the marker variable is recommended by Rönkkö and Ylitalo (2011). Table 6 presents the results for marker variable. The results show that there was no significant change in R2 after the introduction of the marker variable in the model. Hence, pointing towards the absence of common method variance. Table 5 shows the results before and after for the marker variable.

Table 5. Marker Variable

\begin{tabular}{lll}
\hline Constructs & Before Marker Variable & With Marker Variable \\
\hline Creativity & 0.297 & 0.297 \\
Autonomous Motivation & 0.391 & 0.392 \\
Job Complexity & 0.271 & 0.281 \\
\hline
\end{tabular}

Sources: developed by the authors.

Age, education, and years of experience were held as control variables to rule out any variance in the dependent variable beyond independent variables of the study. Knowledge, experience and other demographic variables have shown influence in predicting creative behaviour (Dong et al., 2017; Setiawan, 2017). Gender as a control variable was not included in the study because of the lower number of female respondents. In turn, this study included all the control variables and did not find any change in the $\mathrm{R} 2$ values. Therefore, all the control variables were removed from the base-line model

After ensuring the correct measurement model assessment as per the set criteria, the structural model assessment was performed. Variance inflation factors VIFwas tested among the constructs. It is worth 
A., Fateh, N., Mustamil, M. Z., Aslam. Linking Authentic Leadership and Employee Creative Behavior: The Role of Autonomous Motivation and Job Complexity.

noting that VIF is the test used for detecting multicollinearity among variables. VIF based on the comparing inflation of linear model regression coefficients with the variance of regression coefficients of the nonlinear regression model. Lower values of VIF are described in the model.

Table 6 presents the values of VIF, values of VIF for all the variables of the model are below the cutoff point - VIF $=5.0$ (Hair et al., 2014).

Table 6. Findings of VIF statistics

\begin{tabular}{ll}
\hline Construct & VIF \\
\hline Authentic Leadership $\rightarrow$ Autonomous Motivation & 1.371 \\
Authentic Leadership $\rightarrow$ Job complexity & 1.000 \\
Autonomous Motivation $\rightarrow$ Creativity & 1.641 \\
Job Complexity $\rightarrow$ Autonomous Motivation & 1.371 \\
Job Complexity $\rightarrow$ Creativity & 1.641 \\
\hline
\end{tabular}

Sources: developed by the authors.

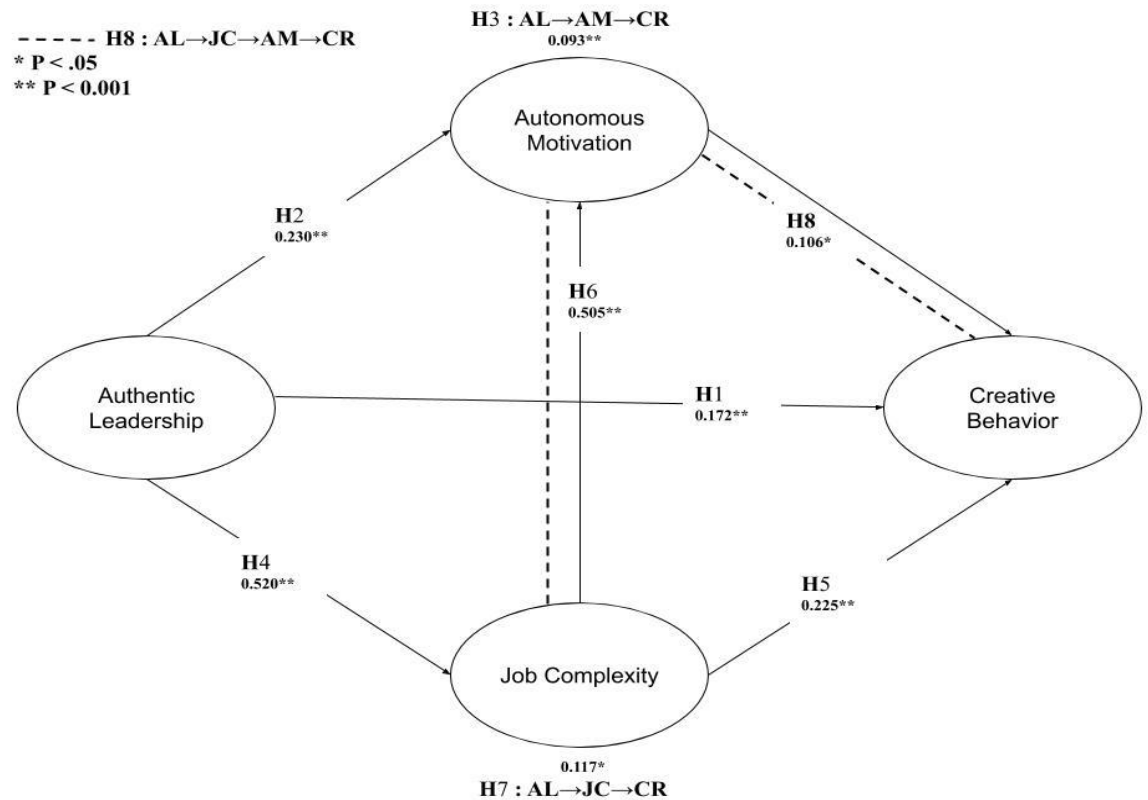

Figure 1. Structural model of the study

Sources: developed by the authors.

After that, the values of the path coefficients of the hypothesized relationship were examined. The values of all path coefficients are within the acceptable range of +1 and -1 . There were bootstrap parameters as follows: Subsamples $=2000$, Bias-corrected and Accelerated $(\mathrm{BCa})$ Bootstrap, No significant change. The power determination criteria for the path coefficient is its proximity to the value of 1 , the closer the values to 1 , the more powerful it would be considered in explaining the R2 of the Model. The next step is to assess the determination of the path coefficient or the value of R2. It is the amount of total variability in the dependent variable that is accounted for by the independent variables of the study (Di Bucchianico, 2008). Value of R2 varies between 0 and 1 . A general rule of thumb is that $R 2 \geq 0.02$ will 
A., Fateh, N., Mustamil, M. Z., Aslam. Linking Authentic Leadership and Employee Creative Behavior: The Role of Autonomous Motivation and Job Complexity.

be considered weak, $R 2 \geq 0.13$ is moderate, and $R 2 \geq 0.26$ can be termed as substantial (Cohen, 1988). R2 for the statistical model of the study is equal to 0.348 , which can be categorized as substantial. Next, there was measured Stone-Geisser's (Q2) for the statistical model. Table 7 shows the values of R2 for autonomous motivation equal to 0.225 , job complexity $=0.261$, and creative behaviour is equal to 0.150 , indicating predictive relevance of the model. If the value of Q2 is above zero, it can be said that the model has predictive relevance (Hair et al., 2014).

Moreover, the directional hypothesis of the study starting from $A L$ and creative behaviour $(A L \rightarrow C R$; $\beta=0.172 ; p=0.001 ; t-V a l u e=2.686 ; 95 \%)$ and $A L$ and autonomous motivation $(A L \rightarrow A M ; \beta=0.230$; $p=0.001 ;$ t-Value $=4.535 ; 95 \%$ ) is significant. Relationship between $A L$ and job complexity is also statistically significant $(A L \rightarrow J C ; \beta=0.520 ; p=0.001 ; t$-Value $=10.403 ; 95 \%)$. Job complexity and autonomous motivation $(\mathrm{JC} \rightarrow \mathrm{AM} ; \beta=0.505 ; p=0.001 ; t$-Value $=11.510 ; 95 \%)$, job complexity and creative behaviour $(\mathrm{CM} \rightarrow \mathrm{CR} ; \beta=0.225 ; p=0.001 ; t$-Value $=3.160 ; 95 \%)$ are all meaningful and statistically significant.

Indirect relationship of the study namely $\mathrm{AL} \rightarrow$ autonomous motivation $\rightarrow$ Creative behaviour $(\mathrm{AL} \rightarrow \mathrm{AM} \rightarrow \mathrm{CR} ; \beta=0.093 ; p=0.001 ; t$-Value $=3.333 ; 95 \%), \mathrm{AL} \rightarrow$ Job complexity $\rightarrow$ creative behaviour $(\mathrm{AL} \rightarrow \mathrm{JC} \rightarrow \mathrm{CR} ; \beta=0.263 ; p=0.001 ; t$-Value $=7.590 ; 95 \%)$ are also significant. Moreover, sequential mediation path for $\mathrm{AL} \rightarrow$ job complexity $\rightarrow$ autonomous motivation $\rightarrow$ creative behaviour $(A L \rightarrow J C \rightarrow A M \rightarrow C R ; \beta=0.106 ; p=0.001 ; t$-Value $=4.563 ; 95 \%)$ is significant and meaningful.

Table 7. Thee reesulta of hypothesis checking

\begin{tabular}{|c|c|c|c|c|c|c|c|c|c|}
\hline & Relationship & $\beta$ & SE & $t$-Value & Cl-LL & Cl-UL & Decision & $\mathbf{R}^{2}$ & Q2 \\
\hline H1 & $\mathrm{AL} \rightarrow \mathrm{CR}$ & 0.172 & 0.064 & 2.686 & 0.052 & 0.306 & Accepted & $\begin{array}{l}0.34 \\
8\end{array}$ & 0.150 \\
\hline $\mathrm{H} 2$ & $\mathrm{AL} \rightarrow \mathrm{AM}$ & 0.230 & 0.051 & 4.535 & 0.129 & 0.331 & Accepted & $\begin{array}{l}0.42 \\
9\end{array}$ & 0.255 \\
\hline H3 & $\mathrm{AL} \rightarrow \mathrm{AM} \rightarrow \mathrm{CR}$ & 0.093 & 0.028 & 3.333 & 0.045 & 0.154 & Accepted & - & - \\
\hline $\mathrm{H} 4$ & $A L \rightarrow J C$ & 0.520 & 0.050 & 10.403 & 0.414 & 0.609 & Accepted & $\begin{array}{l}0.27 \\
1\end{array}$ & 0.261 \\
\hline H5 & $\mathrm{JC} \rightarrow \mathrm{CR}$ & 0.225 & 0.071 & 3.160 & 0.073 & 0.358 & Accepted & - & - \\
\hline $\mathrm{H} 6$ & $\mathrm{JC} \rightarrow \mathrm{AM}$ & 0.505 & 0.044 & 11.510 & 0.412 & 0.588 & Accepted & - & - \\
\hline $\mathrm{H} 7$ & $\mathrm{AL} \rightarrow \mathrm{JC} \rightarrow \mathrm{CR}$ & 0.117 & 0.028 & 2.878 & 0.045 & 0.154 & Accepted & - & - \\
\hline H8 & $\begin{array}{l}\mathrm{AL} \rightarrow \mathrm{JC} \rightarrow \mathrm{AM} \\
\rightarrow \mathrm{CR}\end{array}$ & 0.106 & 0.041 & 4.563 & 0.041 & 0.201 & Accepted & - & - \\
\hline
\end{tabular}

Note: AL is authentic leadership, CR is employee creative behaviour, AM is autonomous motivation, JC is job complexity

Sources: developed by the authors.

The primary objective of the study was to determine the direct relationship between authentic leadership and creative behaviour and the process through which authentic leadership predicts employee creative behaviour. The objective was achieved by conducting a cross-sectional survey study where each respondent was asked to rate himself on his creative behaviour and rate their leader on authentic leadership traits and style. The important contribution of the study is confirming the proposed mediation paths between authentic leadership and employee creative behaviour. Both autonomous motivation and job complexity mediate the relationship between authentic leadership and creativity with different strength. It was found that authentic leadership positively predicts employee creative behaviour. Additionally, authentic leadership has a direct positive direct relationship with job complexity and autonomous motivation. Also, both authentic leadership and job complexity positively predict autonomous motivation. While comparing the relationship between authentic leadership and autonomous motivation and the relationship between job complexity and autonomous motivation, it was found that job complexity is much 
A., Fateh, N., Mustamil, M. Z., Aslam. Linking Authentic Leadership and Employee Creative Behavior: The Role of Autonomous Motivation and Job Complexity.

more effective in predicting autonomous motivation in employees. It confirms the contention, whether an authentic leader is more effective in predicting autonomous motivation or job complexity is more effective in influencing creative behaviour. One possible explanation for this finding can be as follows. To an individual become autonomously motivated, his three basic psychological needs should be fulfilled, and complex work directly meets the need for competence and autonomy (Albrecht, 2015) because of offering multiple methods of performing the job. Whereas, an authentic leader, despite all his positive influence, may not directly fulfil the basic psychological needs. That is why its influence of fulfilling the basic psychological needs reduces in comparison to factors that directly fulfil the basic psychological needs. Moreover, job complexity was found to have a positive direct relationship with employee creative behaviour.

When testing for mechanisms of authentic leadership through which it induces employee creative behaviour, it was found that job complexity, when coupled with authentic leadership, inspire more creative behaviour among employees rather than authentic leader enabling autonomous motivation. Job complexity and autonomous motivation served as the sequential mediator between authentic leadership and creative behaviour. Sequential mediation path has a similar strength of the single mediator path $(\mathrm{AL} \rightarrow \mathrm{AM} \rightarrow \mathrm{CR})$ where autonomous motivation is mediating the relationship between authentic leadership and creative behaviour. These findings provide a complex picture of the mechanisms that were tested in the study model and lead to an interesting finding. An authentic leader is more successful in facilitating the complexity of the work than autonomously motivating his followers. The suggested explanation for these findings is that a leader has direct control over organisational and work-related resources (Northouse, 2009). In contrast, the relationship with employees is much more complicated and multifaceted. Methodologically, in a first, there was tested three pathways of authentic leadership, connecting it with creative behaviour simultaneously, and individually. By highlighting the most important mechanism through which authentic leadership can induce relatively higher creative behaviour, the important implications for managers and researchers were laid down. Moreover, the study provided exploring three different mechanisms and testing them for their relative importance. It was denoted in this research that job complexity is the most important mechanism through which authentic leaders can inspire their followers for creative behaviour. Therefore, managers can provide employees with complex works so they can come up with more ideas for performing the task.

Another important implication is that an authentic leader may not be as effective as a complex job in making an individual autonomously motivated, but an authentic leader can provide an opportunity for complex work, which in return autonomously motivates and employee leading to him exhibiting creative behaviour. By unravelling this sequential mediation process, there was provided with the evidence of the mechanism which makes an authentic leader more effective in promoting creative behaviour in his follower. One limitation of the study was its reliance on a cross-sectional design for testing mediation pathways. It was recommended a longitudinal design for future studies. The current study based its results on self-reported creative behaviour. Self-reported creativity can be a reliable source for reporting creative behaviour but is prone to common method bias. The study has tried to eliminate common method bias with methods prescribed in the literature. However, multiple-source reported creative behaviour would be more effective in reducing common method variance. Therefore, future studies should consider this recommendation. There were tested two single variable mediation mechanism and one sequential mediation process with two variables. Future research should include more mechanisms and reveal their relative effectiveness when used with authentic leadership. The authentic leader has shown to have autonomously motivated his employees in the previous research, but the study shows, it is comparatively less effective when employees have complex work to perform. Perhaps job complexity can be tested as a boundary condition between the relationship between authentic leader and employee creative behaviour. Different personality dispositions can also be tested as a boundary condition between the said relationship. 
A., Fateh, N., Mustamil, M. Z., Aslam. Linking Authentic Leadership and Employee Creative Behavior: The Role of Autonomous Motivation and Job Complexity.

Conclusions. The current study attempted to test the relationship between authentic leadership and employee creative behaviour directly and through two mediating mechanisms. The results of this research show that authentic leadership positively influences employee creative behaviour. The underlying process through which authentic leadership affects employee creative behaviour was confirmed, with both the proposed mediator successfully mediating the relationship with varying degree of strength. Job complexity was found to be the stronger mediator as compared to autonomous motivation between the said relationship. Furthermore, there was explored the sequential mediation between authentic leadership and autonomous motivation and tested job complexity and autonomous motivation as sequential mediators. Results of the sequential mediation confirmed the proposed mediation path as well.

Author Contribution. F. A Conceptualized the study. All the authors contributed equally to the literature review, data collection, research methodology, analysis, and conclusion.

\section{References}

Agote, L., Aramburu, N., \& Lines, R. (2016). Authentic leadership perception, trust in the leader, and followers' emotions in organizational change processes. Journal of Applied Behavioral Science, 52(1), 35-63. [Google Scholar] [CrossRef]

Ahmad, I., Zafar, M. A., \& Shahzad, K. (2015). Authentic leadership style and academia's creativity in higher education institutions: intrinsic motivation and mood as mediators. Transylvanian Review of Administrative Sciences, 11(46), 5-19. [Google Scholar]

Albrecht, S. L. (2015). Challenge demands, hindrance demands, and psychological need satisfaction. Journal of Personnel Psychology, 14(2), 70-79. [Google Scholar] [CrossRef]

Amabile, T. M. (1988). A model of creativity and innovation in organizations. In B. S. Cummings (Ed.), Research in Organizational Behaviour (Vol. 10, pp. 123-167). Greenwich: JAI Press. [Google Scholar]

Amabile, T. M. (1996). Creativity in context: Update to the social psychology of creativity. London: Hachette UK.

Amabile, T. M., \& Pratt, M. G. (2016). The dynamic componential model of creativity and innovation in organizations: Making progress, making meaning. Research in Organizational Behavior, 36, 157-183. [Google Scholar] [CrossRef]

Anderson, M. H., \& Sun, P. Y. T. (2017). Reviewing leadership styles: Overlaps and the need for a new «full-range» theory. International Journal of Management Reviews, 19(1), 76-96. [Google Scholar] [CrossRef]

Anderson, N., De Dreu, C. K., \& Nijstad, B. A. (2004). The routinization of innovation research: A constructively critical review of the state-of-the-science. Journal of Organizational Behavior, 25(2), 147-173. [Google Scholar] [CrossRef]

Anderson, N., Potocnik, K., \& Zhou, J. (2014). Innovation and creativity in organizations: A state-of-the-science review, prospective commentary, and guiding framework. Journal of management, 40(5), 1297-1333.

Avolio, B. J., \& Gardner, W. L. (2005). Authentic leadership development: Getting to the root of positive forms of leadership. Leadership Quarterly, 16(3), 315-338. [CrossRef]

Baer, M., Oldham, G. R., \& Cummings, A. (2003). Rewarding creativity: when does it really matter? The Leadership Quarterly, 14(4), 569-586. [Google Scholar] [CrossRef]

Banks, G. C., McCauley, K. D., Gardner, W. L., \& Guler, C. E. (2016). A meta-analytic review of authentic and transformational leadership: A test for redundancy. The Leadership Quarterly, 27(4), 634-652. [Google Scholar] [CrossRef]

Barroso, C., Carrion, C. G., \& Roldan, J. (2010). Applying maximum likelihood and PLS on different sample sizes: Studies on SERVQUAL model and employee behaviour model. In V. E. Vinzi, W. W. Chin, \& J. Henseler (Eds.), Handbook of Partial Least Squares: Concepts, Methods and Applications. (pp. 427-447). Heidelberg, Berlin Springer. [Google Scholar] [CrossRef]

Boies, K., Fiset, J., \& Gill, H. (2015). Communication and trust are key: Unlocking the relationship between leadership and team performance and creativity. The Leadership Quarterly, 26(6), 1080-1094. [Google Scholar] [CrossRef]

Campbell, D. T., \& Fiske, D. W. (1959). Convergent and discriminant validation by the multitrait-multimethod matrix. Psychological buletinl, 56(2), 81-105. [Google Scholar] [CrossRef]

Chae, H., \& Choi, J. N. (2018). Contextualizing the effects of job complexity on creativity and task performance: Extending job design theory with social and contextual contingencies. Journal of Occupational and Organizational Psychology, 91(2), 316-339. [Google Scholar] [CrossRef]

Chaudhary, R., \& Panda, C. (2018). Authentic leadership and creativity: The intervening role of psychological meaningfulness, safety and work engagement. International Journal of Productivity and Performance Management, 67(9), 2071-2088. [CrossRef]

Christensen-Salem, A., Kinicki, A., Zhang, Z., \& Walumbwa, F. O. (2018). Responses to feedback: The role of acceptance, affect, and creative behavior. Journal of Leadership \& Organizational Studies, 25(4), 416-429. [Google Scholar] [CrossRef] Cohen, J. (1988). Statistical Power Analysis for the Behavioral Sciences (2 Ed.). Hillsdale: Lawrence Erlbaum Associates. [Google Scholar]

de Jesus, S. N., Rus, C. L., Lens, W., \& Imaginario, S. (2013). Intrinsic motivation and creativity related to product: A metaanalysis of the studies published between 1990-2010. Creativity Research Journal, 25(1), 80-84. [Google Scholar] [CrossRef]

http://mmi.fem.sumdu.edu.ua/en 
A., Fateh, N., Mustamil, M. Z., Aslam. Linking Authentic Leadership and Employee Creative Behavior: The Role of Autonomous Motivation and Job Complexity.

Deci, E. L., \& Ryan, R. M. (1985a). The general causality orientations scale: Self-determination in personality. Journal of Research in Personality, 19(2), 109-134. [Google Scholar] [CrossRef]

Deci, E. L., \& Ryan, R. M. (1985b). Intrinsic Motivation and Self-Determination in Human Behavior. New York, US: Springer. [Google Scholar] [CrossRef]

Deci, E. L., Olafsen, A. H., \& Ryan, R. M. (2017). Self-determination theory in work organizations: The state of a science. Annual Review of Organizational Psychology and Organizational Behavior, 4(1), 19-43. [Google Scholar] [CrossRef]

Di Bucchianico, A. (2008). Coefficient of Determination (R2). In R. S. Ruggeri, F. W. Kenett, \& Faltin. (Eds.). Encyclopedia of Statistics in Quality and Reliability: John Wiley \& Sons. [CrossRef]

Dong, Y., Bartol, K. M., Zhang, Z. X., \& Li, C. (2017). Enhancing employee creativity via individual skill development and team knowledge sharing: Influences of dual-focused transformational leadership. Journal of Organizational Behavior, 38(3), 439-458. [Google Scholar] [CrossRef]

Eisenberger, R., \& Cameron, J. (1996). Detrimental effects of reward. Reality or myth? American psychologist, 51(11), 11531166. [Google Scholar] [CrossRef]

Eisenberger, R., \& Cameron, J. (1998). Reward, intrinsic interest, and creativity: New findings. American Psychologist, 53(6), 676-679. [Google Scholar] [CrossRef]

Eisenberger, R., Armeli, S., \& Pretz, J. (1998). Can the promise of reward increase creativity? Journal of personality and social psychology, 74(3), 704-714. [Google Scholar] [CrossRef]

Evans, M. G. (1991). The problem of analyzing multiplicative composites: Interactions revisited. American Psychologist, 46, 615. [Google Scholar] [CrossRef]

Fornell, C., \& Larcker, D. F. (1981). Evaluating structural equation models with unobservable variables and measurement error. Journal of Marketing Research, 18(1), 39-50. [CrossRef]

Franke, G., \& Sarstedt, M. (2019). Heuristics versus statistics in discriminant validity testing: a comparison of four procedures. Internet Research, 29(3), 430-447. [Google Scholar] [CrossRef]

Fried, Y., \& Ferris, G. R. (1987). The validity of the job characteristics model: A review and meta-analysis. Personnel Psychology, 40(2), 287-322. [Google Scholar] [CrossRef]

Gagne, M., \& Deci, E. L. (2005). Self-determination theory and work motivation. Journal of Organizational Behavior, 26(4), 331 362. [CrossRef]

Gagne, M., Forest, J., Vansteenkiste, M., Crevier-Braud, L., Van den Broeck, A., Aspeli, A. K., . . \& Halvari, H. (2015). The multidimensional work motivation scale: Validation evidence in seven languages and nine countries. European Journal of Work and Organizational Psychology, 24(2), 178-196. [Google Scholar] [CrossRef]

Gardner, W. L., Avolio, B. J., \& Walumbwa, F. O. (2005). Authentic leadership theory and practice: Origins, effects and development (Vol. 3). West Yorkshire, England: Emerald Group Publishing Limited.

Gardner, W. L., Cogliser, C. C., Davis, K. M., \& Dickens, M. P. (2011). Authentic leadership: A review of the literature and research agenda. Leadership Quarterly, 22(6), 1120-1145. [Google Scholar] [CrossRef]

Gardner, W., Avolio, B., Luthans, F., May, D. , \& Walumbwa, F. (2005). Can you see the real me? A self-based model of authentic leader and follower development. The Leadership Quarterly, 16(3), 343-372. [CrossRef]

Gefen, D., \& Straub, D. (2005). A practical guide to factorial validity using PLS-Graph: Tutorial and annotated example. Communications of the Association for Information Systems, 16(1), 5. [Google Scholar] [CrossRef]

George, B. (2003). Authentic Leadership: Rediscovering the Secrets to Creating Lasting Value. John Wiley \& Sons. [Google Scholarl

Gosling, S. D., Vazire, S., Srivastava, S., \& John, O. P. (2004). Should we trust web-based studies? A comparative analysis of six preconceptions about internet questionnaires. American Psychologist, 59(2), 93-104. [Google Scholar] [CrossRef]

Hackman, J. R. (1980). Work redesign and motivation. Professional Psychology, 11(3), 445-455. [Google Scholar] [CrossRef]

Hair Jr, J. F., Howard, M. C., \& Nitzl, C. (2020). Assessing measurement model quality in PLS-SEM using confirmatory composite analysis. Journal of Business Research, 109, 101-110. [Google Scholar] [CrossRef

Hair Jr, J. F., Hult, G. T. M., Ringle, C., \& Sarstedt, M. (2016). A primer on partial least squares structural equation modeling (PLS-SEM). Sage publications. [Google Scholar]

Hair, J. F., Ringle, C. M., \& Sarstedt, M. (2011). PLS-SEM: Indeed a silver bullet. Journal of Marketing Theory and Practice, 19(2), 139-152. [Google Scholar] [CrossRef]

Henseler, J., Ringle, C. M., \& Sarstedt, M. (2015). A new criterion for assessing discriminant validity in variance-based structural equation modeling. Journal of the academy of marketing science, 43(1), 115-135. [Google Scholar] [CrossRef]

Hughes, D. J., Furnham, A., \& Batey, M. (2013). The structure and personality predictors of self-rated creativity. Thinking Skills and Creativity, 9, 76-84. [Google Scholar] [CrossRef]

Hughes, D. J., Lee, A., Tian, A. W., Newman, A., \& Legood, A. (2018). Leadership, creativity, and innovation: A critical review and practical recommendations. The Leadership Quarterly, 29(5), 549-569. [CrossRef]

llies, R., Morgeson, F. P., \& Nahrgang, J. D. (2005). Authentic leadership and eudaemonic well-being: Understanding leaderfollower outcomes. The Leadership Quarterly, 16(3), 373-394. [Google Scholar] [CrossRef]

James, K., \& Drown, D. (2012). Organizations and creativity: Trends in research, status of education and practice, agenda for the future. In Handbook of organizational creativity (pp. 17-38). Academic Press. [Google Scholar] [CrossRef] 
A., Fateh, N., Mustamil, M. Z., Aslam. Linking Authentic Leadership and Employee Creative Behavior: The Role of Autonomous Motivation and Job Complexity.

Lee, A., Legood, A., Hughes, D., Tian, A. W., Newman, A., \& Knight, C. (2020). Leadership, creativity and innovation: A metaanalytic review. European Journal of Work and Organizational Psychology, 29(1), 1-35. [Google Scholar]

Lee, N., \& Cadogan, J. W. (2013). Problems with formative and higher-order reflective variables. Journal of Business Research, 66(2), 242-247. [Google Scholar] [CrossRef]

Luthans, F., \& Avolio, B. J. (2003). Authentic leadership development. In K. S. Cameron, J. E. Dutton, \& R. E. Quinn (Eds.), Positive organizational scholarship: Foundations of a new discipline (pp. 241-261). San Francisco: Barrett-Koehler.

Miniotaitè, A., \& Buciuniene, I. (2013). Explaining authentic leadership work outcomes from the perspective of self-determination theory. Management of Organizations: Systematic Research, 65, 63-75. [Google Scholar] [CrossRef]

Mubarak, F., \& Noor, A. (2018). Effect of authentic leadership on employee creativity in project-based organizations with the mediating roles of work engagement and psychological empowerment. Cogent Business \& Management, 5(1), 1-14. [Google Scholar] [CrossRef]

Mumford, M. D., Connelly, M. S., Baughman, W. A., \& Marks, M. A. (1994). Creativity and problem solving: Cognition, adaptability, and wisdom. Roeper Review, 16(4), 241-246. [CrossRef]

Neider, L. L., \& Schriesheim, C. A. (2011). The authentic leadership inventory (ALI): Development and empirical tests. The leadership quarterly, 22(6), 1146-1164. [Google Scholar] [CrossRef]

Nichols, T. W., \& Erakovich, R. (2013). Authentic leadership and implicit theory: a normative form of leadership?. Leadership \& Organization Development Journal. [Google Scholar] [CrossRef]

Northouse, P. G. (2009). Leadership: Theory and Practice (5 Ed.). India: Sage Publications India.

Parker, S. K., Morgeson, F. P., \& Johns, G. (2017). One hundred years of work design research: Looking back and looking forward. Journal of Applied Psychology, 102(3), 403-420. [CrossRef]

Podsakoff, P. M., MacKenzie, S. B., Lee, J. Y., \& Podsakoff, N. P. (2003). Common method biases in behavioral research: a critical review of the literature and recommended remedies. Journal of applied psychology, 88(5), 879. [Google Scholar]

Ramayah, T., Cheah, J., Chuah, F., Ting, H., \& Memon, M. A. (2018). Partial least squares structural equation modeling (PLSSEM) using smartPLS 3.0. In An Updated Guide and Practical Guide to Statistical Analysis. Pearson. [Google Scholar]

Rego, A., Sousa, F., Marques, C., \& Cunha, M. P. E. (2012). Authentic leadership promoting employees' psychological capital and creativity. Journal of Business Research, 65(3), 429-437. [CrossRef]

Rego, A., Sousa, F., Marques, C., \& e Cunha, M. P. (2014). Hope and positive affect mediating the authentic leadership and creativity relationship. Journal of Business research, 67(2), 200-210. [Google Scholar] [CrossRef

Ribeiro, N., Duarte, A. P., Filipe, R., \& Torres de Oliveira, R. (2020). How authentic leadership promotes individual creativity: The mediating role of affective commitment. Journal of Leadership \& Organizational Studies, 27(2), 189-202. [Google Scholar] [CrossRef

Ringle, C. M., Sarstedt, M., Mitchell, R., \& Gudergan, S. P. (2020). Partial least squares structural equation modeling in HRM research. The International Journal of Human Resource Management, 31(12), 1617-1643. [CrossRef]

Ringle, C. M., Silva, D., \& Bido, D. (2014). Structural equation modeling with the smartpls. Revista Brasileira de Marketing 13(2), 56-73. [Google Scholar] [CrossRef]

Rönkkö, M., \& Ylitalo, J. (2011). PLS marker variable approach to diagnosing and controlling for method variance. [Google $\underline{\text { Scholarl }}$

Ryan, R. M., \& Deci, E. L. (2000). Self-determination theory and the facilitation of intrinsic motivation, social development, and well-being. American Psychologist, 55(1), 68-78. [Google Scholar]

Ryan, R. M., \& Deci, E. L. (2003). On assimilating identities to the self: A self-determination theory perspective on internalization and integrity within cultures. In M. R. Leary \& J. P. Tangney (Eds.), Handbook of self and identity. (pp. 253-272). New York: The Guilford Press. [Google Scholar]

Sajjad, M., Riaz, A., Orangzab, Chani, M., \& Hussain, R. (2020). Innovations in human resources management: Mediating role of intrinsic motivation. Marketing and Management of Innovations(1), 110-120. [CrossRef]

Sarstedt, M., Hair Jr, J. F., Cheah, J. H., Becker, J. M., \& Ringle, C. M. (2019). How to specify, estimate, and validate higherorder constructs in PLS-SEM. Australasian Marketing Journal (AMJ), 27(3), 197-211. [Google Scholar] [CrossRef]

Sarstedt, M., Ringle, C. M., Cheah, J. H., Ting, H., Moisescu, O. I., \& Radomir, L. (2020). Structural model robustness checks in PLS-SEM. Tourism Economics, 26(4), 531-554. [Google Scholar] [CrossRef]

Semedo, A. S. D., Coelho, A. F. M., \& Ribeiro, N. M. P. (2017). Authentic leadership and creativity: The mediating role of happiness. International Journal of Organizational Analysis, 25(3). [Google Scholar] [CrossRef]

Setiawan, R. (2017). The Influence of Income, Experience, and Academic Qualification on the Early Childhood Education Teachers' Creativity in Semarang, Indonesia. International Journal of Instruction, 10(4), 39-50. [Google Scholar]

Shmueli, G., Ray, S., Estrada, J. M. V., \& Chatla, S. B. (2016). The elephant in the room: Predictive performance of PLS models. Journal of Business Research, 69(10), 4552-4564. [Google Scholar] [CrossRef]

Sue, V. M. \& Ritter. L. A. (2012). Planning the online survey. Conducting online surveys, 14-32. [Google Scholar]

Tierney, P., \& Farmer, S. M. (2002). Creative self-efficacy: Its potential antecedents and relationship to creative performance. Academy of Management journal, 45(6), 1137-1148. [Google Scholar] [CrossRef]

Tierney, P., Farmer, S. M., \& Graen, G. B. (1999). An examination of leadership and employee creativity: The relevance of traits and relationships. Personnel psychology, 52(3), 591-620. [Google Scholar] [CrossRef]

http://mmi.fem.sumdu.edu.ua/en 
A., Fateh, N., Mustamil, M. Z., Aslam. Linking Authentic Leadership and Employee Creative Behavior: The Role of Autonomous Motivation and Job Complexity.

Toor, S. U. R., \& Ofori, G. (2008). Leadership for future construction industry: Agenda for authentic leadership. International Journal of Project Management, 26(6), 620-630. [Google Scholar] [CrossRef]

Tracy, B. (2010). How the best leaders lead: Proven secrets to getting the most out of yourself and others. New York, USA: Amacom. [Google Scholar]

Van Der Vegt, G., Emans, B., \& Van De Vliert, E. (2000). Team members' affective responses to patterns of intragroup interdependence and job complexity. Journal of management, 26(4), 633-655. [Google Scholar] [CrossRef]

Walumbwa, F. O., Avolio, B. J., Gardner, W. L., Wernsing, T. S., \& Peterson, S. J. (2008). Authentic leadership: Development and validation of a theory-based measure. Journal of management, 34(1), 89-126. [Google Scholar] [CrossRef]

Xu, B. D., Zhao, S. K., Li, C. R., \& Lin, C. J. (2017). Authentic leadership and employee creativity: Testing the multilevel mediation model. Leadership \& Organization Development Journal, 38(3), 482-498. [Google Scholar] [CrossRef]

Zaitouni, M., \& Ouakouak, M. L. (2018). The impacts of leadership support and coworker support on employee creative behavior. International Journal of Productivity and Performance Management, 67(9), 1745-1763. [Google Scholar] [CrossRef

Zhou, J., \& Ren, R. (2012). Striving for creativity: Building positive contexts in the workplace. In K. S. Cameron \& G. Spreitzer (Eds.), The Oxford Handbook of Positive Organizational Scholarship. UK: Oxford Univesrity Press.

Zubair, A., \& Kamal, A. (2017). Perceived authentic leadership, psychological capital, and creative work behaviour in bank employees. Pakistan Journal of Psychological Research, 32(1), 35-53.

Аднан Фатех, Університет Малайї, Малайзія

Норізах Мустаміл, Ph.D., Університет Малайї, Малайзія

Мухаммад Зія Аслам, Університет Малайї, Малайзія

Взаємозв'язок між автентичним лідерством та креативною поведінкою працівників: посередницька роль мотивації та складності роботи

У статті проаналізовано вплив рівня складності роботи та мотивації на лідерські здібності на рівень крективності працівників. Головною метою дослідження є визначення взаємозв'язку між лідерством та креативною поведінкою працівників. Підгрунтям дослідження стали результати інтернет-опитування 354 респодентів щодо оцінювання рівня креативності працівників при виконанні робочих обов'язків. Детерміновану вибірку даних сфрормовано на основі результатів опитування співробітників (переважно розробників програмного забезпечення) програмно-технічних центрів Пакистану. У статті проаналізовано взаємозв'язок між змінними за допомогою методу моделювання частково-найменших квадратів структурних рівнянь (PLS-SEM). Встановлено, що ефрективність управління має прямий позитивний вплив на творчу поведінку працівників. При цьому мотивація та складність роботи $\epsilon$ посередниками,через які автентичне лідерство впливає на рівень креативності співробітників. Авторами доведено, що складність роботи та автономна мотивація успішно виконували функції посередників між автентичним лідерством та креативною поведінкою працівників. Отримані результати дослідження становлять практичну та теоретичну цінність. Так, практикуючі менеджери можуть використовувати розроблений авторами процес розвиткку креативної поведінки працівників за допомогою автентичного стилю керівниитва. У свою чергу, висновки дослідження щодо механізмів, через які автентичне лідерство впливає на креативну поведінку працівників та прогнозує ії розвиток можуть бути корисними для науковців. Очікується, що рзультати даного дослідження сприятимуть подальшому розвитку автентичної теорії лідерства як предиктора успішного виконання робочих обов'язків співробітниками. Подальшого дослідження потребують підходи до оцінюваання рівня кретивності працівників з метою елімінування суб'єктивізму та самооцінювання.

Ключові слова: автентичне лідерство, автономна мотивація, креативність, креативна поведінка працівників, складність роботи, теорія садетермінації, програмотехнічна компанія Пакистану, розробники програмного забезпечення

Manuscript received: 19.05.2020

(C) The author(s) 2020. This article is published with open access at Sumy State University 